effective than hydrochlorothiazide in a substantial number of hypertensive patients.

The Verapamil versus Diuretic (VERDI) Trial Research Group comprises: Steering committee - A Distler, H Holzgreve (chairman), J Michaelis, T Philipp. Working party-A Distler (Berlin), A Eckardt (Ludwigshafen), W Gauß (Ludwigshafen), G Hilgenstock (Berlin), H Holzgreve (Munich), J Michaelis (Mainz), G Pfennigsdorf (Ludwigshafen), T Philipp (Essen), S Wellek (Mainz). Investigators J Kindler, B Heintz (Aachen), D Kraft, W Pusch, H Reitzig (Berlin), B Schmaltz (Bingen), R M Lederle (Dortmund), W Kirch, G Wensing, G Loose (Essen and Kiel), E Keidl (Geisenheim), H C Burck (Kiel), H W Karch (Kirn), C Osiecki (Koblenz), B Hinkelmann (Kuppenhein), W D Pfund (Lauf an der Pegnitz), K H Rahn, R Böhm, H Petri (Maastricht), G E von Manteuffel (Marburg), K Irmscher, C Credner, B Baumeister (Mönchengladbach), M Middeke (Munich), V Heinze, H F Benzing, G Mielke (Offenburg), J Zehner, L Weber, D Schmid-Hösl (Passau), H Dobbelstein, W Härtl, W Weber-Guskar (Tutzing), R Ernst (Wiesbaden), F Schardt, W Gross (Würzburg)

This study was supported by a grant from Knoll AG, Ludwigshafen, Federal Republic of Germany.

1 Memorandum from the WHO/ISH. 1986 guidelines for the treatment of mild hypertension. Hypertension 1986;8:957-61.

2 Deutsche Liga zur Bekämpfung des hohen Blutdrucks. Empfehlungen zur Hochdruckbehandlung in der Praxis und zur Behandlung hypertensiver Notfälle. 7th ed. 1986.
Medical Research Council Working Party. MRC trial of treatment of mild hypertension: principal results. Br Med f 1985;291:97-104.

4 The IPPPSH Collaborative Group. Cardiovascular risk and risk factors in randomized trial of treatment based on the beta-blocker oxprenolol: the international prospective primary prevention study in hypertension (IPPPSH). 7 Hypertens 1985;3:379-92.

5 Wilhelmsen L, Berglund G, Elmfeldt D, et al. Beta-blockers versus diuretic in hypertensive men: main results from the HAPPHY trial. $f$ Hyperten 1987;5:561-72.

6 Bühler FR. Age and cardiovascular response adaptation. Determinants of an antihypertensive treatment concept primarily based on beta-blockers and calcium entry blockers. Hypertension 1983;5(suppl III):94-100.

7 Zanchetti A. Role of calcium antagonists in systemic hypertension. Am f Cardiol 1987:59:130-6B.

8 Weber $F$, Anlauf $M$. Direkte und indirekte Vergleichsuntersuchungen zur Meßgenauigkeit des elektronischen Blutdruckmeßgerätes Tonomed. Herz Kreislauf 1982;5:279-83.

9 Breslow NE, Day NE. Statistical methods in cancer research. Vol 1. The analysis of case control studies. Lyons: IARC Scientific Publications, 1980:142-6.

10 Veterans Administration Cooperative Study Group on Antihypertensive Agents. Comparison of propranolol and hydrochlorothiazide for the initial treatment of hypertension. I. Results of short-term titration with emphasis on racial differences in response. $\mathcal{F} A M A$ 1982;248:1996-2003.

11 Freis ED, Materson BJ, Flamenbaum W. Comparison of propranolol and hydrochlorothiazide alone for treatment of hypertension. III. Evaluation of the renin-angiotensin system. Am f Med 1983;74: 1029-41.

12 Frishman WH, Zawada ET, Smith LK, et al. Comparison of hydrochlorothiazide and sustained-release diltiazem for mild-to-moderate systemic hypertension. Am f Cardiol 1987;59:615-23.

13 Berglund G, Andersson O. Low doses of hydrochlorothiazide in hypertension. Antihypertensive and metabolic effects. Eur $\mathcal{F}$ Clin Pharmacol 1976;10 $177-82$

14 Sarachek NS, London RL, Matulewicz TH. Diltiazem and granulomatous hepatitis. Gastroenterology 1985;88:1260-2.

15 Zimmerman HJ, Maddrey WC Toxic and drug-induced hepatitis. In: Schiff L, Schiff ER, eds. Diseases of the liver. 6th ed. Philadelphia: Lippincott, 1987:644.

(Accepted 11 August 1989 )
Department of Community Medicine,

Medical School,

Edinburgh EH8 9AG

Vera Carstairs, BSC, honorary

fellow

Russell Morris, BSC, research

officer

Correspondence and requests for reprints to:

Mrs Carstairs.

Br.Med f 1989:299:886-9

\title{
Deprivation: explaining differences in mortality between Scotland and England and Wales
}

\author{
Vera Carstairs, Russell Morris
}

\section{Abstract}

To detect reasons for the difference in mortality between Scotland and England and Wales a measure of deprivation was studied, comprising overcrowding, unemployment of men, low social class, and not having a car. Data for Scotland for 1980-2 showed this measure to be strongly associated with mortality, with gradients being particularly steep in young adults. Deprivation was much more severe in Scotland than in England and Wales. These findings suggest that much excess mortality may be ascribed to more adverse conditions. Standardising the mortality ratios to take account of the relative affluence and deprivation of the two populations led to the differentials observed being radically adjusted, while standardising for social class had little effect. Deprivation measures based on areas overcome many of the limitations associated with social class analysis and also show much greater discrimination between populations.

Measures of deprivation apparently provide a powerful basis for explanation of health differences. Such measures should therefore form part of the 1991 census output to facilitate their use on a consistent basis.

\section{Introduction}

Mortality within the United Kingdom differs, with England having the lowest and Scotland and Northern Ireland vying for the place at the top of the league. Factors that may explain these differences are not easily identified, though selective migration, poorer diet, higher levels of smoking, and the more unfavourable climate may all contribute. We present evidence on the association between mortality and a measure of deprivation in Scotland and England and Wales that suggests that much excess mortality could be associated with the more adverse socioeconomic circumstances experienced in Scotland, deprivation presenting a picture of differences in the populations that is not present in the distribution of social class.

\section{Method}

We calculated deprivation scores for the postcode sectors in Scotland and wards in England and Wales from the 1981 census and mortality for $1980-2$ by age, sex, and category of deprivation for Scotland, which provided the basis for calculating expected deaths in England and Wales. Compared with the observed deaths these provided standardised mortality ratios that took into account differences in the material circumstances of the two populations.

The deprivation measure was based on four census variables: overcrowding, unemployment among men, low social class, and not having a car. These were combined into a single score for each postcode sector in Scotland $(n=$ about $100 \overline{0})$ by means of the $Z$ score technique. The value of each component variable for a sector was standardised to have a mean of zero and standard deviation of 1 by subtracting the mean value for the population (or Scotland) and then dividing by its respective population standard deviation. The four standardised component variables were then added together into one score that had a population mean of zero and standard deviation of 1 . The resulting distribution was split on an arbitrary basis into seven categories ranging from very affluent to very deprived. These categories were designed to maintain the discrimination in the population, with most being allocated to the three middle categories and smalle 
proportions of roughly equal numbers at the extremes. Other methods of determining these class intervals would give slightly different results but would not affect the general pattern of mortality. The means and standard deviations of the four census variables were also used to calculate the scores for 9265 wards in England and Wales (wards of City of London combined) so that they were on a comparable basis. The wards were also allocated to the seven categories that had already been determined, and the populations by age and sex in each category were aggregated over all wards to give totals for England and Wales.

All deaths in Scotland in 1980-2 (190000) were allocated to a postcode sector except for deaths of people not resident in Scotland (1647). Death rates by age, sex, and category of deprivation were calculated for Scotland within the database by aggregating deaths and populations (by age and sex) over all sectors within each category of deprivation. Expected numbers of deaths for England and Wales were calculated by using the (age-sex) Scottish death rates applied to the England and Wales populations firstly, by age and sex and, secondly, by age, sex, and category of deprivation. These were then compared with the observed (reported) deaths in 1980-2 to provide standardised mortality ratios (observed/expected $\times 100$ ) with a base of Scotland $=100$. By simple arithmetic the values were converted to England and Wales $=100$. Standardised mortality ratios were calculated for the age group 0-64 and all ages as the differentials between countries of the United Kingdom are known to be greater at younger ages. We could not standardise mortality for all ages or 0-64 by using the more customary basis of social class because of lack of population data, but this procedure was carried out for men aged 20-64 by using data from the occupational mortality report.'

TABLE II - Proportion (\%) of population living at differing categories of deprivation, Scotland and England and Wales

\begin{tabular}{cccc}
\hline $\begin{array}{c}\text { Deprivation } \\
\text { score }\end{array}$ & $\begin{array}{c}\text { Deprivation } \\
\text { categoryt }\end{array}$ & Scotland & $\begin{array}{c}\text { England and } \\
\text { Wales }\end{array}$ \\
\hline$<-1.4-$ & 1 & $6 \cdot 1$ & 23.8 \\
$-1 \cdot 4-$ & 2 & 13.7 & 30.4 \\
$-0 \cdot 8-$ & 3 & 21.8 & 21.5 \\
$-0 \cdot 3-$ & 4 & 25.5 & 14.1 \\
$0 \cdot 3-$ & 5 & 14.8 & 6.7 \\
$0 \cdot 8-$ & 6 & 11.4 & 2.9 \\
$>1.7$ & 7 & 6.8 & 0.5
\end{tabular}

*Population of Scotland 5035000 ; England and Wales 48552000. $+1=$ Affluent, $7=$ deprived

TABLE III-Death ratios by age and sex for deprivation categories. Overall death rate for each age-sex group $=\overline{1} 00, \bar{S}$ cotland, $1980-2$

\begin{tabular}{|c|c|c|c|c|c|c|c|c|c|}
\hline \multirow[b]{2}{*}{ Age } & \multirow[b]{2}{*}{ Sex } & \multicolumn{7}{|c|}{ Deprivation category* } & \multirow[b]{2}{*}{ No of deaths } \\
\hline & & 1 & 2 & 3 & 4 & 5 & 6 & 7 & \\
\hline $0 \cdot 4$ & $\left\{\begin{array}{l}M \\
F\end{array}\right.$ & $\begin{array}{l}79 \\
63\end{array}$ & $\begin{array}{l}81 \\
87\end{array}$ & $\begin{array}{l}97 \\
90\end{array}$ & $\begin{array}{l}102 \\
101\end{array}$ & $\begin{array}{l}111 \\
112\end{array}$ & $\begin{array}{l}105 \\
110\end{array}$ & $\begin{array}{l}124 \\
138\end{array}$ & $\begin{array}{l}1568 \\
1147\end{array}$ \\
\hline $5-$ & $\left\{\begin{array}{l}M \\
F\end{array}\right.$ & $\begin{array}{l}73 \\
81\end{array}$ & $\begin{array}{r}78 \\
100\end{array}$ & $\begin{array}{l}108 \\
102\end{array}$ & $\begin{array}{r}105 \\
86\end{array}$ & $\begin{array}{r}86 \\
106\end{array}$ & $\begin{array}{l}104 \\
117\end{array}$ & $\begin{array}{l}141 \\
106\end{array}$ & $\begin{array}{l}375 \\
239\end{array}$ \\
\hline $15-$ & $\left\{\begin{array}{l}M \\
F\end{array}\right.$ & $\begin{array}{l}70 \\
66\end{array}$ & $\begin{array}{r}89 \\
113\end{array}$ & $\begin{array}{r}111 \\
96\end{array}$ & $\begin{array}{r}101 \\
84\end{array}$ & $\begin{array}{r}97 \\
117\end{array}$ & $\begin{array}{r}94 \\
113\end{array}$ & $\begin{array}{l}127 \\
113\end{array}$ & $\begin{array}{r}1247 \\
427\end{array}$ \\
\hline $25-$ & $\left\{\begin{array}{l}M \\
F\end{array}\right.$ & $\begin{array}{l}53 \\
32\end{array}$ & $\begin{array}{l}77 \\
79\end{array}$ & $\begin{array}{l}86 \\
84\end{array}$ & $\begin{array}{l}105 \\
102\end{array}$ & $\begin{array}{l}108 \\
126\end{array}$ & $\begin{array}{l}123 \\
121\end{array}$ & $\begin{array}{l}173 \\
184\end{array}$ & $\begin{array}{r}1190 \\
625\end{array}$ \\
\hline $35-$ & $\left\{\begin{array}{l}M \\
F\end{array}\right.$ & $\begin{array}{l}55 \\
75\end{array}$ & $\begin{array}{l}68 \\
77\end{array}$ & $\begin{array}{l}87 \\
88\end{array}$ & $\begin{array}{r}102 \\
95\end{array}$ & $\begin{array}{l}110 \\
107\end{array}$ & $\begin{array}{l}139 \\
138\end{array}$ & $\begin{array}{l}181 \\
166\end{array}$ & $\begin{array}{l}2246 \\
1460\end{array}$ \\
\hline $45-$ & $\left\{\begin{array}{l}M \\
F\end{array}\right.$ & $\begin{array}{l}57 \\
65\end{array}$ & $\begin{array}{l}72 \\
75\end{array}$ & $\begin{array}{l}86 \\
92\end{array}$ & $\begin{array}{r}96 \\
100\end{array}$ & $\begin{array}{l}115 \\
105\end{array}$ & $\begin{array}{l}140 \\
130\end{array}$ & $\begin{array}{l}153 \\
145\end{array}$ & $\begin{array}{l}6702 \\
4325\end{array}$ \\
\hline $55-$ & $\left\{\begin{array}{l}M \\
F\end{array}\right.$ & $\begin{array}{l}66 \\
64\end{array}$ & $\begin{array}{l}81 \\
79\end{array}$ & $\begin{array}{l}90 \\
92\end{array}$ & $\begin{array}{l}98 \\
99\end{array}$ & $\begin{array}{l}110 \\
112\end{array}$ & $\begin{array}{l}123 \\
.125\end{array}$ & $\begin{array}{l}140 \\
127\end{array}$ & $\begin{array}{l}16596 \\
10588\end{array}$ \\
\hline $65-$ & $\left\{\begin{array}{l}M \\
F\end{array}\right.$ & $\begin{array}{l}82 \\
79\end{array}$ & $\begin{array}{l}87 \\
88\end{array}$ & $\begin{array}{r}94 \\
104\end{array}$ & $\begin{array}{l}101 \\
100\end{array}$ & $\begin{array}{l}105 \\
108\end{array}$ & $\begin{array}{l}116 \\
114\end{array}$ & $\begin{array}{l}126 \\
127\end{array}$ & $\begin{array}{ll}30 & 160 \\
23 & 120\end{array}$ \\
\hline$\geqslant 75$ & $\left\{\begin{array}{l}M \\
F\end{array}\right.$ & $\begin{array}{l}92 \\
96\end{array}$ & $\begin{array}{l}92 \\
95\end{array}$ & $\begin{array}{l}97 \\
98\end{array}$ & $\begin{array}{l}103 \\
100\end{array}$ & $\begin{array}{l}105 \\
105\end{array}$ & $\begin{array}{l}105 \\
103\end{array}$ & $\begin{array}{l}114 \\
110\end{array}$ & $\begin{array}{l}33971 \\
54288\end{array}$ \\
\hline $\begin{array}{l}0-64 \\
\geqslant 65 \\
\text { All ages }\end{array}$ & & $\begin{array}{l}64 \\
90 \\
83\end{array}$ & $\begin{array}{l}79 \\
92 \\
89\end{array}$ & $\begin{array}{l}91 \\
96 \\
95\end{array}$ & $\begin{array}{r}98 \\
101 \\
100\end{array}$ & $\begin{array}{l}110 \\
105 \\
107\end{array}$ & $\begin{array}{l}125 \\
108 \\
113\end{array}$ & $\begin{array}{l}141 \\
118 \\
125\end{array}$ & $\begin{array}{r}3 \cdot 8 / 1000 \\
66 \cdot 4 / 1000 \\
12 \cdot 6 / 1000\end{array}$ \\
\hline
\end{tabular}

$\star 1=$ Affluent, 7 = deprived.
TABLE IV - Standardised mortality ratios for Scotland $v$ England and Wales, 1980-2, and observed numbers of deaths

\begin{tabular}{|c|c|c|c|c|}
\hline & \multicolumn{2}{|c|}{ Age and $\operatorname{sex}^{\star}$} & \multicolumn{2}{|c|}{ Age, sex, and deprivation } \\
\hline & & England and & & England and \\
\hline & Scotland & Wales & Scotland & Wales \\
\hline \multicolumn{5}{|c|}{ Scotland $=100$} \\
\hline Ages 0-64 & & 82 & & 97 \\
\hline All ages & & 89 & & 97 \\
\hline \multicolumn{5}{|c|}{ England and Wales $=100$} \\
\hline Ages 0-64 & 122 & & 103 & \\
\hline All ages & 112 & & 103 & \\
\hline \multicolumn{5}{|l|}{ Observed deaths $(1000 \mathrm{~s})$ : } \\
\hline Ages 0-64 & $48 \cdot 8$ & $393 \cdot 3$ & & \\
\hline All ages & $190 \cdot 5$ & $1741 \cdot 1$ & & \\
\hline \multicolumn{5}{|c|}{ Great Britain $=100 \ddagger$} \\
\hline Men aged 20-64 & 124 & 98 & 123 & 98 \\
\hline Observed deaths $(1000 \mathrm{~s})$ & $37 \cdot 5$ & $299 \cdot 6$ & & \\
\hline
\end{tabular}

* Except for Great Britain $=100$, when standardised for age alone. †Except for Great Britain $=100$, when standardised for age and social class. $\ddagger 1979-80$ and $1982-3$.

All data are computed from census populations and may differ slightly from published statistics.

TABLE v-Social class distributions (\%), Scotland and England and Wales

\begin{tabular}{|c|c|c|c|c|}
\hline \multirow[b]{2}{*}{ Social class } & \multicolumn{2}{|c|}{ Men aged $20-64^{\prime}$} & \multicolumn{2}{|c|}{ Population ${ }^{\star \star}$} \\
\hline & Scotland & $\begin{array}{l}\text { England and } \\
\text { Wales }\end{array}$ & Scotland & $\begin{array}{l}\text { England and } \\
\text { Wales }\end{array}$ \\
\hline I & $5 \cdot 4$ & $5 \cdot 6$ & $4 \cdot 5$ & $4 \cdot 5$ \\
\hline II & $19 \cdot 1$ & 21.9 & 14.9 & $19 \cdot 1$ \\
\hline III (Non-manual) & 9.9 & $10 \cdot 8$ & $8 \cdot 8$ & $9 \cdot 2$ \\
\hline III (Manual) & $36 \cdot 3$ & $33 \cdot 4$ & $28 \cdot 1$ & $26 \cdot 1$ \\
\hline IV & $17 \cdot 1$ & $15 \cdot 3$ & $12 \cdot 8$ & $12 \cdot 1$ \\
\hline $\mathrm{V}$ & $7 \cdot 3$ & 5.5 & $5 \cdot 2$ & $4 \cdot 0$ \\
\hline In forces or inadequately & & & & \\
\hline $\begin{array}{l}\text { described } \\
\text { Not economically active }\end{array}$ & 4.9 & $3 \cdot 0$ & $2 \cdot 4$ & $2 \cdot 4$ \\
\hline Not economically active & 3.6 & $4 \cdot 4$ & $22 \cdot 7$ & $23 \cdot 5$ \\
\hline
\end{tabular}

*Population in households with head in social class stated and economically

Population figures: men in Scotland 1382000 , England and Wales 13634000 ; population in Scotland 5035000 , England and Wales 48552000 .

\section{Results}

Table I shows the average values of the four variables that made up the deprivation score for Scotland and for England and Wales (though these were not used to calculate the scores); the data show the more adverse conditions experienced in Scotland on all four measures, the discrepancy being most distinct for overcrowding, with a quarter living with more than one person per room in Scotland compared with less than $6 \%$ in England and Wales. The distribution of the Scottish population among the categories of deprivation (table II) shows $62 \%$ in the three middle categories and $6-7 \%$ in the most affluent and most deprived. These proportions compare with $4-5 \%$ in social classes I and $\mathrm{V}$ (see table $\mathrm{V}$ ).

For England and Wales the mean value of the deprivation scores for the wards calculated on the Scotland basis was almost 1 SD from the mean $(0.97)$ and well within the more affluent half of the distribution (table II), and thus nearly $24 \%$ of the population of England and Wales was living in affluent conditions (category 1), which were attained by only $6 \%$ in Scotland; and 18\% in Scotland were living in deprived conditions (categories 6 and 7), which were experienced by only 3-4\% in England and $\mathrm{W}^{\prime}$ ales.

These data serve to underline the essentially relative nature of this score. Within Scotland $45 \%$ of the population was living in areas with positive scoresthat is, in the more deprived half of the distributionbut in relation to the mean value for England and Wales over $80 \%$ were found in categories (3-7) showing greater deprivation than this mean value compared with around $45 \%$ in England and Wales. Equally in Scotland less than $20 \%$ had scores more favourable 
than this mean value (in categories 1 and 2) compared with around 54\% in England and Wales.

The mortality ratios specific for age and sex for each of the seven categories of deprivation showed gradients (table III) that, apart from those for ages 5-14 and 15-24 (which were affected by low numbers of events), showed consistent increases in mortality with deprivation. The gradient was strongest in the age groups 25-34 and 35-44 and diminished with increasing age, though it was still present at 75 and over. (For purposes of comparison table III shows ratios but the actual rates for each cell used as the basis for standardising are available on request.)

The application of Scottish mortality to the populations of England and Wales resulted in standardised mortality ratios (men and women) at age 0-64 of 82 (Scotland $=100$ ) and at all ages of 89 , when standardised on age and sex alone (table IV). Transforming to a base of England and Wales $=100$ gave values of 122 for Scotland at 0-64 and 112 at all ages. Adjusting for differences in deprivation in the two populations had a big impact on the standardised mortality ratios: they were adjusted to 97 (both age groups) for England and Wales or to 103 for Scotland when converted to the England and Wales basis. For men aged 20-64 standardising for differences in social class produced only a negligible effect, the standardised mortality ratios for Scotland being adjusted from 124 to 123 on a Great Britain basis. This slight effect was not surprising as the two populations of men differed little on this measure (table V), and this was also the case for the population generally.

Within Scotland we could standardise the mortality for health boards for men aged 20-64 (by using detailed population data by social class not available from the routine census small area statistics). While standardising by age and social class had little effect on the values, adjusting for category of deprivation (as well as age) resulted in major changes, the populations being markedly diverse in terms of deprivation but not of social class.

\section{Discussion}

Mortality in Scotland is well known to exceed that in England and Wales as is seen for most age groups in the rates specific for age and sex for 1980-2 (table VI). For all ages the standardised mortality ratios for Scotland in 1981 (on a United Kingdom basis) were 115 (males) and 116 (females), $17 \%$ and $18 \%$ above the ratios of 98 for both sexes for England and Wales. ${ }^{+}$

TABLE VI - Mortality (per 1000 population) for Scotland and England and Wales, 1980-2

\begin{tabular}{|c|c|c|c|c|}
\hline \multirow[b]{2}{*}{ Age (years) } & \multicolumn{2}{|c|}{ Scotland } & \multicolumn{2}{|c|}{ England and $W_{\text {ales }}$} \\
\hline & $M$ & $\mathrm{~F}$ & $M$ & $\mathrm{~F}$ \\
\hline $0-$ & $3 \cdot 3$ & $2 \cdot 5$ & $3 \cdot 1$ & $2 \cdot 4$ \\
\hline 5. & $0 \cdot 3$ & $0 \cdot 2$ & $0 \cdot 3$ & $0 \cdot 2$ \\
\hline $15-$ & 1.0 & 0.3 & 0.8 & 0.3 \\
\hline $25-$ & $1 \cdot 1$ & $0 \cdot 6$ & 0.9 & 0.5 \\
\hline 35. & $2 \cdot 6$ & 1.6 & 1.8 & $1 \cdot 3$ \\
\hline 45 & $8 \cdot 0$ & 4.9 & $6 \cdot 1$ & $3 \cdot 7$ \\
\hline $55-$ & 21.9 & $12 \cdot 3$ & $17 \cdot 7$ & $9 \cdot 6$ \\
\hline $65-$ & $53 \cdot 2$ & $30 \cdot 2$ & $48 \cdot 1$ & $25 \cdot 2$ \\
\hline$\geqslant 75$ & 134.9 & $99 \cdot 1$ & $122 \cdot 5$ & $90 \cdot 3$ \\
\hline
\end{tabular}

The differentials have persisted over many years, though by 1985 the standardised mortality ratio had fallen slightly to 112 for both sexes; set against this, however, Scotland had replaced Northern Ireland, which, from having the highest mortality in 1981, had fallen to second place by $1985 .^{+}$The excess mortality we have reported on an age-sex basis of $12 \%$ greater in Scotland than England and Wales at all ages and $22 \%$ at $0-64$ is consistent with these data, though the differen- tials are slightly less pronounced, possibly because we used the census population base.

The differentials are more extreme at younger ages: standardised mortality ratios for Scotland are 124 for men aged 20-64 and 130 for married women aged $20-59$-that is, $27 \%$ and $34 \%$ above the values for England and Wales of 97 for both sexes (on a Great Britain basis). ${ }^{\prime}$

Scotland is also seen to be considerably more deprived. The more adverse conditions in the country as a whole had already been noted in 1971 in the first major analysis of deprivation at small area level, which concluded that "the problems of the Scottish cities, especially Clydeside, stand out most starkly." In 1971 Scotland had $53.6 \%$ of the enumeration districts in Great Britain with overcrowded households, 34.5\% with men unemployed, $35.9 \%$ with no car, and $21.9 \%$ with low social group (socioeconomic group 11) compared with having only $11 \%$ of all enumeration districts. These differentials still persisted in 1981 and may be observed both in the values for the components of deprivation (table II) and in the distributions of the categories of deprivation (table III).

The gradients in mortality by category of deprivation are pronounced, particularly in younger adults, and the vast differences seen in the material circumstances of the two populations suggest that a large part of the excess mortality in Scotland may be attributed to the greater deprivation experienced in that country, the excess being reduced to only $3 \%$ for both age groups when these circumstances are taken into account. There are no strong differences in composition by social class, on the other hand, and these fail to explain the differentials in mortality for men aged 20-64, and it is unlikely that they would do so for the more extended population. As with social class the measure of deprivation describes differentials in mortality, and the determinants of these differences must be sought in other factors: in inborn characteristics, infant experience, environmental influences, and health related behaviour.

The use of Scottish mortality by deprivation to calculate expected deaths for England and Wales was necessary as comparable data for England and Wales were not available. Similar gradients are probably also found within England: data from the Northern region" showed a relation of mortality (at 0-64) with a measure of deprivation that is essentially similar to that found in Scotland - that is, a ratio of around $2 \cdot 2$ in the standardised mortality ratios for wards in the best and worst tenths, which agrees exactly with the ratio of $2 \cdot 2$ derived from the values of 64 in the most affluent and 141 in the most deprived categories in Scotland (table 1).

The measure of social class has served well over many decades to chart the differentials in mortality

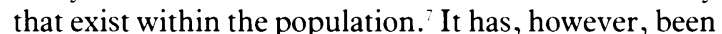
the focus of much criticism in recent years based on theoretical considerations-lack of homogeneity within a social class and changes in the allocation of occupations over time ${ }^{x}$; methodological issues-bias resulting from lack of agreement in recording occupation on the census document and at registration of death'; and problems of interpretation due to the discrete nature of the classification. ${ }^{9}$ In addition, large proportions of the population are not classified: in the 1981 census $42 \%$ of women aged 16-64 were not assigned to an occupation on their own account compared with $12 \%$ of men of the same age, and $68 \%$ of death certificates for women aged 20-59 do not record their occupation compared with $3 \%$ for men aged $20-64^{\prime}$; the $23 \%$ of the population who are retired are also routinely excluded from analysis. The consequence is that analysis by social class (of routinely collected data) has mainly been confined to the exami- 
nation of deaths in the population under the age of 65 (by using husband's or father's occupation for analysis of women and children), though the longitudinal study has managed to extend analysis to older age groups ${ }^{10}$ and to cancer registration data ${ }^{11}$ and the general household survey annual report also provide analysis of health measures by socioeconomic group.

These difficulties have led to proposals for alternative measures of social stratification ${ }^{12}$ and to the adoption of an area based method of analysis. ${ }^{13}$ The near universal use of postcodes as a basis for area classification means that most events can be allocated geographically, thus overcoming many of the limitations described. In addition, compared with social class deprivation measures show distinct discrimination between populations. Classification of the population on the basis of the area in which it lives could therefore provide a valuable alternative strategy for analysis of data in relation to socioeconomic characteristics and enhance the possibilities of epidemiological examination of an extended range of routine health data for which social class is mostly not available. The continuous nature of a deprivation score also offers greater flexibility in analysis.

Debate about the ideal composition of a deprivation measure ${ }^{1+}$ is hardly likely to be resolved, though better measures of relative disadvantage could be constructed if government departments would make available at small area level some of the information on income (inland revenue) and supplementary benefits (social security) on the same basis as unemployment statistics. " Our own measure seems as robust as any other candidate in explaining variations in health (unpublished data); it correlates strongly not only with the standardised mortality ratio for ages $0-64(0.75)$ but also with the census measure of the percentage of the population (in private households) reporting themselves as unable to work due to permanent sickness
$(0 \cdot 77)$ and adheres to the concept of deprivation of material resources in a way that is not true for all such measures proposed. To promote its use on a consistent basis we suggest that the census output for 1991 should incorporate one or more similar measures; this would facilitate access to them and, by providing uniform measures, increase the comparability of data emerging from studies that use this approach in analysis.

This research was funded by the chief scientist, Scottish Home and Health Department. We thank the Office of Population Censuses and Surveys for use of published data, the registrar general, Scotland, for supplying census and mortality data, and Brian Jarman and Madhavi Bajekal for calculating the deprivation scores for wards of England and Wales.

1 Office of Population Censuses and Survers. Occupational mortality decennial supplement 1979-80, 1982-3. London: HMSO, 1986

2 Office of Population Censuses and Surveys and General Register Office Scotland. Census 1981, key statistics for urban areas. Scotland, England and Wales. London: HMSO, 1984.

3 Carstairs V, Morris R. Deprivation and mortality: an alternative to social class? Community Med 1989;11:210-9.

Office of Population Censuses and Survers. Mortalty statstess 1980-2. London: HMSO, 1983-4. Series DH1 Nos 9, 12, 13

Holterman S. Areas of deprivation in Great Britain: an analysis of 1971 census data. Social Trends 1975:6:33-47.

6 Townsend P Phillimore P Beatie A. Healsh and deprivation: inequality and the north. London: Croom Helm, 1988.

Townsend P, Davidson N, Whitehead M, Black D, eds. Inequalities in health the Black report and the health divide. Harmondsworth: Penguin, 1988

Jones IG, Cameron D. Social class analysis: an embarrassment to epidemiology. Community Med 1984;6:37-46.

Community Med 1984;6:37-46.
Stern J. Social mobility and the interpretation of social class mortality Stern J. Social mobility and the interpretation of
differentials. Fournal of Social Policy 1983;12:27-49.

10 Fox AJ, Goldbutt P. Socioeconomic differentials in mortality 1971-75. London: HMSO, 1982. (Office of Population Censuses and Surveys series LS1.

Leon D. Social distribution of cancer 1971-75. London: HMSO), 1988. (Office of Population Censuses and Survers Series LS3.

12 Goldthorpe J, Hope K. The social classification of occupations: a new approach and scale. Oxford: Clarendon Press, 1974.

13 Carstairs V. Small area analvsis and health service research. Community Med 1981;3:131-9

14 Townsend P. Deprivation. Fournal of Social Policy 1987;16:125-46.

15 Department of Environment. Unemployment statistics for small areas. Emplovment Gazette 1984;92:393-9.

Accepted 1 A ugust 1989
Medical Research Council

Environmental

Epidemiology Unit,

Southampton General

Hospital, Southampton

SO9 4XY

C A C Wickham, MSC,

statistician

K Walsh, MRCP,

epidemiologist

C Cooper, MRCP,

epidemiologist

D J P Barker, FRCP, director

B M Margetts, PHD,

nutritionist

$\mathrm{J}$ Morris, PHD, research

assistant

Department of Medicine for the Elderly, St Helen's

Hospital, Hastings, East Sussex

S A Bruce, MRCP, consultant geriatrician

Correspondence to:

Professor Barker.

Br 118.4.7 1989:299-889-92
Abstract

Objective-To determine whether low dietary calcium intake and physical inactivity are risk factors for hip fracture among subjects aged 65 and over.

Design-Fifteen year follow up study of a large cohort of randomly selected elderly people living in the community, who had taken part in the 1973-4 survey of the Department of Health and Social Security, and for whom dietary and other data were recorded at initial interview and medical assessment.

Setting-Eight areas in Britain (England (five), Wales (one), and Scotland (two)).

Subjects - 1688 Subjects living in the community, of whom 1419 subjects ( 720 men and 699 women) agreed to participate. 1356 Subjects completed a seven day dietary record and 983 (542 men and 441 women) agreed to be assessed by a geriatrician.

Results - Incidence of hip fracture increased with age and was higher in women than men. Comparison with matched controls showed no evidence that the risk of hip fracture was related to calcium intake: the odds ratio for the lowest third of dietary calcium compared with the highest was 0.7 (95\% confidence interval 0.1 to 3.9 ) after adjustment for smoking and body mass index. The adjusted odds ratio for the lowest third of outdoor activity compared with the highest was $4.3(0.7$ to 26.8$)$, and that for grip strength was $3.9(0.7$ to 23.0$)$.

Conclusions-Reduced intake of dietary calcium does not seem to be a risk factor for hip fracture. Further evidence is provided that physical activity in the elderly protects against hip fracture.

\section{Introduction}

An important issue in public health is whether supplementation of calcium in the diet of elderly people will prevent osteoporosis and hip fracture. Evidence on the relation between calcium intake and risk of fracture from cross cultural and case-control comparisons is inconsistent..$^{2}$ In a recent case-control study in southern Britain there was no relation between calcium intake and hip fracture in women, but men with daily intakes above $1 \mathrm{~g}$ had lower risks. ${ }^{3}$

The only reported prospective study is a 14 year follow up study of 957 men and women living in an upper middle class white community in California, in which the risk of hip fracture was inversely related to dietary calcium. ${ }^{+}$From this it was concluded that the risk might be reduced by increasing consumption of 